\title{
Social Accountability of Medical Schools and Social Representations of Medical Students in the Context of the More Doctors Program
}

\author{
Responsabilidade Social das Escolas Médicas \\ e Representações Sociais dos Estudantes de \\ Medicina no Contexto do Programa Mais \\ Médicos
}

\author{
Felipe Proenço de Oliveiral ${ }^{I \Phi}$ \\ Leonor Maria Pacheco Santos ${ }^{I I}$ \\ Helena Eri Shimizu ${ }^{I !}$
}

\section{PALAVRAS-CHAVE}

- Educação Médica.

- Faculdades de Medicina.

- Recursos Humanos em Saúde.

- Atenção Básica à Saúde.

- Programa Mais Médicos.
${ }^{I}$ Universidade Federal da Paraíba, João Pessoa, Paraíba, Brasil.

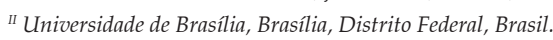

Diversos debates, no contexto nacional e internacional, têm sugerido a necessidade de mudanças na formação médica, de modo que ela esteja em consonância com a organização dos sistemas de saúde. Nessa perspectiva, propõe-se que as escolas sejam orientadas pela responsabilidade social, que consiste em ordenar o ensino, a pesquisa e as atividades em serviço para atender às necessidades em saúde com foco prioritariamente em áreas de difícil acesso. Uma referência mais recente na formação médica em nível nacional foi o Programa Mais Médicos, que dispôs sobre um novo marco regulatório para a educação médica. Avalia-se que as modificações introduzidas pelo programa podem influenciar a elaboração de novas representações sociais dos estudantes de Medicina. Por meio da teoria das representações sociais, realizou-se um estudo qualitativo para analisar a percepção sobre a responsabilidade social das escolas médicas de 149 estudantes de Medicina do sétimo semestre de quatro cursos de instituições federais de ensino superior da Região Nordeste. Dois dos cursos estão no interior e foram criados em virtude do Programa Mais Médicos e outros dois correspondem aos cursos de capitais com mais de 60 anos de existência. Com base na análise do currículo de cada curso, eles foram denominados "tradicionais" ou "novos". Nos resultados, observou-se que os estudantes dos diferentes cursos se assemelham no que diz respeito ao ingresso por cotas, mas os estudantes de cursos "novos" têm maior ingresso por políticas afirmativas, incluindo critérios regionais de acesso. Ambos os grupos de estudantes destacaram prioritariamente o termo "dever", o que pode remeter a um âmbito mais individual da noção de responsabilidade. Também foram citados com destaque nos dois grupos os termos "cidadania" e "ética". Somente os estudantes das escolas "novas" citaram termos como "compromisso", "justiça" e "SUS". Essa percepção sugere uma noção mais ampla da responsabilidade social nos estudantes de escolas criadas em virtude do Programa Mais Médicos, apesar da literatura nacional insuficiente sobre esse tema. Conclui-se ressaltando a importância desse programa na implantação de escolas médicas em regiões que anteriormente não contavam com essa formação. Reforça-se ainda a relevância da dedicação dos professores que implantaram os cursos no interior da Região Nordeste, demonstrando a necessidade de se aprofundar nas temáticas que envolvem o desenvolvimento docente. Sugere-se ampliar as análises sobre experiências como essas, de modo que possam ser aprofundadas com a radicalidade necessária ao fortalecimento do Sistema Único de Saúde. 


\section{KEY-WORDS}

- Medical Education.

- Medical Schools

- Human Resources.

- Primary Care.

- More Doctors Program.

Recebido em: 18/3/19

Aceito em: 20/5/19

\section{INTRODUCTION}

It is known that universal health systems are important to improve the life conditions of populations and, at the same time, to tackle significant injustices in different countries ${ }^{1}$. The training and distribution of health professionals, generally focusing on doctors, has been one of the critical issues considered in strengthening health systems and building equity ${ }^{2}$.

One of the most recent landmarks in the international discussion about the training and distribution of health professionals was the 2010 document from the World Health Organization (WHO) entitled Increasing access to health workers in remote and rural areas through improved retention ${ }^{3}$, which addressed four possible dimensions to increase the access to health professionals and retain them in remote regions. Among these dimensions are educational initiatives, where
ABSTRACT

Several debates, in the national and international context, have suggested the need for changes in in education, so that it is in line with the organization of health systems. From this perspective, that schools be guided by social accountability, which consists of ordering teaching, more recent reference in medical education at the national level was the More Doctors Program, which provided for a new regulatory framework for medical education. It is evaluated that the modifications introduced by the Program can influence the elaboration of new social representations of medical students. Through the theory of social representations, a qualitative study was carried out to analyze the perception about the social accountability of the medical schools of 149 medical students, of the seventh semester of four courses of Federal Higher Education Institutions in the Northeast Region. Two of the courses are in the interior and were created by virtue of the More Doctors Program and another two correspond to courses in the state capital existing for more than 60 years. From the curriculum analysis of each course, they were termed "traditional" or "new". In the results, it was observed that the students of the different courses resemble each other in terms of admission by quotas, but students of "new" courses have a greater entrance under affirmative action policies, including regional access criteria. Both groups of students have emphasized the term "duty" as a priority, which may refer to a more individual scope of the notion of accountability. The terms "citizenship" and "ethics" were also highlighted in both groups. Only for students in "new" schools were terms such as "commitment", "justice" and "SUS" cited. This insight suggests a broader notion of social accountability in school students created under the More Doctors Program, despite insufficient national literature on this topic. The conclusion emphasizes the importance of the Program in the implantation of medical schools in regions that did not previously have this training. It also reinforces the relevance of the dedication of the teachers who implemented the courses in the interior of the Northeast, demonstrating the need to deepen in the themes that involve teacher development. It is suggested that there is a need to broaden the analysis of experiences such as these, so that they can be explored with the radicalism necessary to strengthen the Unified Health System. 
ry, the new reform movement criticizes the sub-specialized and hospital-centric training and argues that training cannot be disconnected from the social determinants of health and, therefore, the organization of the local health system. Once again, it criticizes the medical school that aims only to reproduce itself, but does not converse with other relevant stakeholders in health and, principally, does not concern itself with the way that its graduates act in the health services ${ }^{6}$.

In harmony with this movement, new proposals arose and were consolidated for modifying medical training, represented by international consortiums that, on principle, respect autonomy and local characteristics. Obviously, this is not the first time that changing medical training has been discussed, as it is possible to list various previous movements. In the scope of the Americas, for example, movements have been recorded since the 1950s and 1960s, captained by the Pan-American Health Organization (PAHO), which aims to meet the social demands for doctors with training appropriate to health systems.

One of the examples that is highlighted in these movements is a working group promoted by $\mathrm{PAHO}$ to prepare minimum requirements for creating medical schools ${ }^{7}$. The participants extrapolated the initial objectives of the group and ended up also seeking strategies to change existing schools. This resulted in one of its important assumptions, which is (in Spanish): "El fin último del sistema de formación de recursos humanos para la salud, no es formar profesionales, sino mejorar la salud de la población". ("The end purpose of the system of training human resources for health, is not to train professionals, but to improve the health of the population") (p. 265).

Accordingly, the issues analyzed in this article cannot be characterized as a recent discussion, although this debate has advanced and retreated at different times (or, at least, undergone a certain stagnation). At the same time, the change in training has gained new outlines in the recent context, for example with the consortiums already cited, guided by the idea of social accountability in medical education.

Among these consortiums, there is noteworthy output from the Training for Health Equity Network ${ }^{8}$ and the Global Consensus for Social Accountability for Medical Schools ${ }^{9}$, which bring together medical schools from different continents and seek accreditation formats for schools that come to be declared as socially accountable. In the most recent scope specific to the Americas, $\mathrm{PAHO}$ aims to encourage new changes among the schools, with a landmark a meeting being held in Brazil in 2014, which generated the report (in Spanish) $\mathrm{La}$ misión social de la educación médica para alcanzar la equidad em salud ${ }^{10}$ (The social mission of health education to achieve equity in health).
Social accountability in medical education - translated as "responsibilidade social" in Brazil - and also known by the term "social mission" ("missão social") - refers to the institutional responsibility to guide training, research and in-service activities to meet health needs, with the priority focus on areas where access is difficult ${ }^{8}$. This concept arises from the perception that aiming for health is also to aim for social justice, understanding that the medical school must have the obligation to direct training, research and extension activities to address the priority health concerns of the community, for the region or for the nation in which it resides ${ }^{11}$.

These definitions, therefore, lead to the concept of a medical school in close harmony with the health system, which some authors describe in specific experiences as being a health-school system ${ }^{12}$. In schools that adopt the perspective of social accountability, it is argued that they must make an explicit contribution to the health system, demonstrating, for example, that the doctors trained have a positive impact on the health indicators of their communities ${ }^{13}$.

The Global Consensus for Social Accountability for Medical Schools ${ }^{9}$ lists ten directives for action from the perspective of social accountability: anticipating society's health needs; partnering with the health system and other stakeholders; adapting to the evolving roles of doctors and other health professionals; fostering outcome-based education; creating responsive and responsible governance of the medical school; refining the scope of standards for education, research and service delivery; supporting continuous quality improvement in education, research and service delivery area; establishing mandated mechanisms for accreditation; balancing global principles with context specificity; defining the role of society.

Even the concept of social accountability is under debate, there being, for example, the formulation from Boelen et al. ${ }^{14}$, in which the differences between accountability, responsibility and responsiveness are discussed. For these authors, these three terms are adopted to describe the gradient of differences and capacity for change between the schools, where the term accountability - or "responsibilidade social" as the present authors translate it in Brazil - would indicate the most advanced stage that a Medical course could reach.

The school characterized by responsibility would be committed to social well-being and the education of good doctors. At another level, the school adopting responsiveness aims to respond to the health priorities in a location: training doctors with specific competencies and with an eye on professionalism. Finally, the school with accountability works collaboratively with governments, health organizations and society, aiming for a positive impact on the health of people, being capable of 
demonstrating that its work is relevant, of high quality, equitable and cost-effective ${ }^{14}$.

Therefore, the social accountability term translated by the present authors into Portuguese as responsabilidade social aims for greater coverage, but must be used with care, so as not to give the appearance of newness to something that aims to maintain conservative structures or the status quo ${ }^{15}$. It is exactly from this perspective that Ritz et al. ${ }^{5}$ propose critical reflexivity social accountability: originating from the Northern Ontario School of Medicine, a medical school considered to be socially accountable, which participates in international consortiums, the authors analyze in what way the term "social accountability" is becoming an "umbrella" that has come to cover conservative guidance matrices, which aim only to reproduce the medical school in patterns similar to the reforms influenced by the Flexner Report ${ }^{6}$.

Surpassing this perspective means reflecting on the contradiction of processes where the actors at medical schools, who originate from the most privileged classes, plan the needs of the working classes. Having this in mind, it is proposed to continue to use the term social accountability, but include the "critical and reflexive" view to establish initiatives such as: constantly re-examining the processes and the role of each stakeholder in them; contextualizing the local social, political and cultural situation; making social accountability a substantive enterprise, aiming to tackle injustice and evaluating its impact; sharing the power between the medical school and other stakeholders.

Despite the growing international literature on the theme and the initiatives in the region of the Americas, national references on social accountability are still insufficient. One of the few is the report mentioned above, with regard to an event held in Brazil in 2014 on the social mission ${ }^{10}$. There is also the translation into Portuguese of the initiative of the Global Consensus for Social Accountability for Medical Schools from the Foundation for Advancement of International Medical Education and Research (Faimer) ${ }^{16}$.

In the national arena, there are various well-qualified landmarks in the debate about medical training, and it is not intended to describe them in this article. Among the initiatives can be cited the Health Care Training Project (IDA - Integração Docente Assistencial) of the 1970s and the "New Initiative in Health Professional Education: United with the Community" (UNI - Uma Nova Iniciativa na Educação dos Profissionais de Saúde: União com a Comunidade) in the 1990s, which advocated greater integration between teaching, service and community ${ }^{17}$. Another society initiative in the 1990s was the National Inter-institutional Commission on Medical Education
Evaluation (Cinaem - Comissão Interinstitucional Nacional de Avaliação do Ensino Médico), consisting of different entities, most medical corporations, and which extrapolated the scope of the evaluation and proposed changes on four fronts (management, in-service placement, professionalized training, and evaluation) to transform medical education ${ }^{18}$.

The most recent initiatives for changing training have been in the government sphere ${ }^{19}$, such as the National Reorientation Program for Health Professional Training (Pró-Saúde - Programa Nacional de Reorientação da Formação Profissional em Saúde), the Education Program for Working in Health (PET-Saúde - Programa de Educação pelo Trabalho em Saúde) and the Program for Valuing the Primary Healthcare Professional (Provab - Programa de Valorização do Profissional da Atenção Básica). However, the most wide-ranging recent initiative has been the More Doctors Program (MDP) (in Brazil, PMM - Programa Mais Médicos), launched in July 2013, which has been characterized by legal provisions and actions involving the Ministry of Health and Ministry of Education to change training ${ }^{20}$.

The proposals in the scope of training for the MDP were for a new regulatory landmark in Brazilian medical education, aiming to reorganize the process for opening Medical courses and medical residence places, prioritizing health regions with the weakest relationship between places and doctors per capita, but which have health service structures capable of offering fields of practice appropriate to the training. Therefore, by virtue of the MDP, various Medical courses were created in the interior of the country. Law 12.871/2013 established new National Curricular Directives (DCN - Diretrizes Curriculares Nacionais), setting the conditions for opening and operating courses to effectively implement them, which were published in $2014^{21}$.

Considering this recent context of introducing new modifications to medical training, the aim here is to analyze the perception of Medical students, on courses created before the MDP and on courses created because of this program, about the social accountability of the medical school.

\section{METHODOLOGY}

This is a qualitative study, guided by the theories of social representation. Four Medical courses at federal Higher Education Institutions (HEI) in the Northeast Region were selected for this research. This included two created under the More Doctors Program, with campuses in the interior of their states. The other two had been operating for at least 60 years, corresponding to courses in the state capitals, from the same HEI as the course in the interior. 
From the analysis of the curriculums of these courses it could be seen that the older courses had isolated subjects involving primary healthcare placements and that the predominant methodology was oral transmission (lectures). On this basis, these have been called "traditional". For the courses created under the More Doctors Program, the curriculum was structured as proposed in the DCN of 2014, with active teaching/learning methodologies by means of tutorials and weekly and longitudinal primary healthcare placements. Considering these characteristics, these courses have been called "new".

The research took place between July and September 2017, with students in the seventh semester of these courses being invited to participate. This semester corresponds to the stage that the first intake on the "new" courses had reached, being, therefore, the most advanced with which it was possible to develop the research instruments. The project was approved by the Ethics Committee for Research with Human Beings of Faculty of Health Sciences in the University of Brasília under Opinion no. 1.852.717.

Among the 198 students registered on the seventh semester of this course, 159 were present in the lesson on the day on which the research was presented. Of these, 149 agreed to participate voluntarily in the study, being 68 from "traditional" courses and 81 from "new" courses. Initially, the participants answered a sociodemographic questionnaire, based on questions similar to those applied in the National Student Performance Examination (Enade - Exame Nacional de Desempenho dos Estudantes). They then completed a free recall script, in which they cited three words that occurred to them immediately in relation to the term "social accountability". Next, the students numbered, in order of importance, written words or expressions to prioritize the items ${ }^{22,23}$.

The data from the sociodemographic questionnaire were analyzed using the Statistical Package for the Social Sciences (SPSS) program, version 23.0. Univariate analysis was conducted and the frequency distribution constructed. The words cited in the free recall script were analyzed using the Interface de $R$ pour les Analyses Multidimensionnelles de Textes et de Questionnaires software (Iramuteq), which uses word tables to enable the social representation structure to be identified. The prioritization was also processed using the software, so as to reinforce or re-evaluate the placement of these terms.

In this way, categories and words were prioritized in coherence with the analysis performed from the viewpoint of the qualitative research, aiming to summarize the most significant structures presented by the interviewees and perform a summary effort without suppressing the richness of the information $^{24}$. The analysis of the students responses was conducted by means of the theory of social representation ${ }^{25}$, using the complementary theory of the central nucleus ${ }^{22}$.

Social representations are symbolic elements that individuals express through the use of words and gestures. They can also be defined as messages mediated by language, constructed socially and necessarily anchored within the context of the individual who produces them ${ }^{24}$. When the representation of an object is created, the subject is also represented. When the subject expresses an opinion on an object, it is assumed that they make a contribution to developing a representation ${ }^{26}$.

For the objectives of this research, the concepts of central nucleus and peripheral nucleus as defined by Sá ${ }^{27}$ were also used. The central nucleus is marked by the collective memory, reflecting the historic, sociological and ideological conditions of the group; consisting of a common, consensual base, collectively shared in the representations, providing homogeneity to the social group. It is stable, coherent and resistant to chance, thereby ensuring the continuity and the consistency of the representation; it is relatively insensitive to the social context and immediate material in which the representation manifests itself. While the peripheral nucleus permits individual and historic experiences to be integrated; it supports the heterogeneity of the group and the contradictions; it evolves and is sensitive to the immediate context.

\section{RESULTS AND DISCUSSION}

The questions for profiling the participants in this step are shown in Table 1, split between participants in the "traditional" schools and "new" schools. It can be seen there are a series of similarities between the groups with regard to the sex, civil status, secondary school education and motivation for studying Medicine. At the same time, there are notable differences in variables such as age, family income, parents' educational level, current employment, entry through affirmative action policies, the presence of doctors in the family, and the reason for choosing the HEI.

A similarity between the groups relates to the type of school at which the student received secondary education: in both groups, the number is about $30 \%$ of students originate from state schools and around 70\% from private schools. The Quotas Law $^{28}$ stipulated that HEIs must have a percentage of $50 \%$ coming from state schools in the year 2016. For the year of entry of the students in this study (2014), this percentage had to be at least $25 \%$. It is considered, therefore, that this proportion is in agreement with the provisions of the Law for all of the institutions participating in this research. However, Ristof $^{29}$ argues that this percentage is still insufficient; the author questions the goal of achieving only $50 \%$ of places for entry 


\section{TABLE 1}

Sociodemographic profile of the students participating in the research in "traditional" and "new" schools. Brazil 2017

Type of Medical school

"Traditional" school $(\mathrm{N}=68)$

Variables

Frequency

Proportion

"New" school ( $=81)$

Sex

(n) (\%)

"Nuency

Female

$33 \quad 48.5$

Male

35

48.5

(n)

Proportion

Age

20 to 24 years old

25 years old or older

51.5

42

39

(\%)

No response

$50 \quad 73.6$

$12 \quad 17.6$

Civil Status

Married

6

17.6

8.8

49

Single

Stable union

$\begin{array}{cc}1 & 1.5 \\ 66 & 97.1 \\ 1 & 1.5\end{array}$

Mother's educational level

None

$0 \quad 0$.

0.0
8.8

Primary school

Secondary school

$\begin{array}{cc}6 & 8.8 \\ 16 & 23.5\end{array}$

Higher education

\section{7}

Post graduate

$27 \quad 39.7$

19

27.9

31

31
1

1

\section{9}

69
3

Father's educational level

None

Primary school

Secondary school

Higher education

1.5

8.8

32.4

Post graduate

38.3

19.1

1

85.2
3

Family income (minimum salaries)

Up to 1.5

1.5 to 3

3 to 4.5

4.5 to 6

6 to 10

Over 10

$\begin{array}{cc}1 & 1.5 \\ 6 & 8.8 \\ 22 & 32 . \\ 26 & 38.3 \\ 13 & 19.1\end{array}$

1

15

\section{2}

18.5

27.2

32.1

21.0

Financed by government program

Yes $\quad 10 \quad 14.7$

No

58

$8 \quad 11.8$

11.8
11.8

$\begin{array}{ll}8 & 11.8 \\ 9 & 13.2\end{array}$

13.2

27.9

22.1

22
26

17

Working

Yes
No

Entry through affirmative action policy

Yes

62

85.3

\section{2}

2.5

27.2

29.6

29.6

11.1

No

\section{49}

8.8

8.8
91.2

24

24

9

Predominant secondary education school

Private

Public

47

21

91.2

4.7

27.9

72.1

\section{1}

13.6

19.8

18.5

18.5

9.9

19.8

Doctor in the family

Yes

\section{1}

57

30.9

\section{1}

16.2

16.2
83.8

4.4

23.5

22.1

50.0

8.6

91.4

Principal reason for choosing Medicine

$\begin{array}{lc}\text { Family influence } & 3 \\ \text { Labor market } & 16 \\ \text { Professional appreciation } & 15 \\ \text { Vocation } & 34\end{array}$

Principal reason for choosing the HEI

$\begin{array}{lcc}\text { Ease of access } & 0 & 0.0\end{array}$

0.0
22.1

7.4

67.6

Quality

Only one offering a place

$\begin{array}{cr}15 & \\ 5 & 7.4 \\ 46 & 67.6\end{array}$

Source: The authors.

2.9
14.8

85.2

45.7

54.3

69.1

30.9

27.2

72.8

4.9

18.5

12.3

64.2

2.5

42.0

17.3

30.9

7.4 
from state schools, given that Brazilian secondary education is essentially delivered by the state, corresponding to $87 \%$ of student registrations.

A difference to be highlighted relates to the entry by affirmative action policies, understood to be "[...] special measures that aim to eliminate the imbalances between determined social categories until they are neutralized" (p. 844) ${ }^{30}$. For this purpose, it is necessary for effective measures to be taken in favor of the categories that are found to be disadvantaged. Thus, the affirmative action policies bring the prospect of eliminating historic inequalities, aiming for equality of opportunity for socially excluded groups and populations ${ }^{31}$.

For Haas and Linhares ${ }^{30}$, the objectives of the affirmative action policies are: to combat the discrimination that happens in certain spaces in society; to reduce the inequality that affects determined groups; to achieve social transformation; to enable access to the school and to the labor market; to integrate different social groups in the existing spaces, valuing cultural diversity. To Dias Sobrinho ${ }^{32}$, the greater purpose for affirmative action policies is to promote social inclusion of some marginalized groups, such that these policies often end up collaborating for the development of some peripheral regions.

For Ristoff ${ }^{29}$, it is important to prepare a pathway so that more aggressive inclusion policies become politically viable. At the same time, Haas and Linhares ${ }^{30}$ argue that extending the affirmative action policies is only possible through open discussion with the academic community, which they argue plays a fundamental role in the production of knowledge and the delivery of social needs. At this point, it is worth highlighting the context in which the "new" schools were created: as Reuni states, an important phenomenon in Brazilian higher education has been the increase in financing for public institutions ${ }^{33}$.

Therefore, it is possible to argue that the new schools have had a more favorable context for establishing the affirmative action policies by virtue of the expansion of higher education. It is also a suggested role for the More Doctors Program, considering that, for authors like Nascimento ${ }^{34}$, the new Medicine curricular directives provide a favorable context to use affirmative action policies in a school created on a new HEI campus.

This finding can be reinforced by the fact that the schools created by virtue of the More Doctors Program are, in this study, HEIs that have adopted their own affirmative action policies, for example, the Regional Inclusion Argument (AIR Argumento de Inclusão Regional) ${ }^{34}$. The AIR involves increasing the mark in the Unified Selection System by up to $20 \%$ for the students. To obtain this, they must have completed primary education and studied in secondary education in normal schools, on-site, in the micro-regions where the HEI campuses in the study are located. Nascimento ${ }^{34}$ views this as a successful policy, having demonstrated that students coming from the regions covered do effectively enter the course.

Continuing the analysis, with regard to the free recall instrument completed by the students, the results are presented in Figures 1 and 2, which summarize the findings from the free recall and the prioritization of the items at the time at which the participant in the research was presented with the term "social accountability" for the "traditional" course (Figure 1) and "new" courses (Figure 2).

The upper left quadrant shows the most frequently and promptly recalled words, being indicators of the central nucleus of the representation. The upper right quadrant is the first periphery, where the words have high frequency although they were not so promptly mentioned. The bottom left quadrant corresponds to the contrast zone, with low frequency elements, put promptly recalled, and the bottom right quadrant is the second periphery, with low recall and frequency ${ }^{35}$.

Figure 1

Prototypical analysis of the terms recalled by the students of the "traditional" Medical courses when questioned about "social accountability". Brazil, 2017

\begin{tabular}{|c|c|}
\hline Central Zone & First Periphery \\
\hline $\begin{array}{l}\text { Duty }-17-1.7 \\
\text { Empathy - } 10-1.9 \\
\text { Ethics - 8-1.2 } \\
\text { Commitment - } 7-1.7 \\
\text { Important - 6-1.8 } \\
\text { Citizenship - 5- } 1.4 \\
\text { Equity - 4 - } 1.8 \\
\text { Collectivity - } 4\end{array}$ & $\begin{array}{l}\text { Conscience }-6-2.3 \\
\text { Care }-6-2.3 \\
\text { Policy }-5-2 \\
\text { Rights }-4-2.5 \\
\text { Justice }-4-2.5 \\
\text { Obligation }-4-2.5\end{array}$ \\
\hline Contrasting Elements & Second Periphery \\
\hline $\begin{array}{l}\text { Education }-3-1.7 \\
\text { Essential }-3-1.7 \\
\text { Attitude }-2-1 \\
\text { Health }-2-1.5 \\
\text { Inclusion }-2-1 \\
\text { Altruism }-2-1.5\end{array}$ & $\begin{array}{l}\text { Government }-3-2.3 \\
\text { Respect }-3-2 \\
\text { Necessary }-3-2.7 \\
\text { Equality }-3-2 \\
\text { Work }-3-2 \\
\text { Proactivity }-2-3 \\
\text { All }-2-2 \\
\text { Hypocrisy }-2-2 \\
\text { Difficulty }-2-2.5 \\
\text { Society }-2-2 \\
\text { Action }-2-2.5\end{array}$ \\
\hline
\end{tabular}

Source: The authors.

For the purpose of analysis, this work focused mainly on the terms of the central nucleus, first periphery and contrasting elements, considering the relevance of the terms to the training for the social representations of the Medical students. In both groups, that is, in the central nucleus for both the 


\section{Figure 2}

Prototypical analysis of the terms recalled by

the students on the "new" Medical courses when

questioned about "social accountability". Brazil, 2017

Central Zone
Duty - $15-1.6$
Commitment - $12-1.1$
Ethics - 6-1.3
Justice - 5- 1.6
Important - 5-1.6

First Periphery

Empathy - $15-2$

Care $-8-1.9$

Necessary $-7-2$

Equity $-6-2.3$

Equality $-6-2.2$

Citizenship -6-2

Obligation - 5-2.4

Contrasting Elements

Second Periphery

Autonomy $-3-1.3$

Contribution $-3-1.3$

Moral - 3-1.3

Competence - 2-1.5

Vocation - 2 - 1.5

All - 2- 1.5

SUS - 2 - 1.5

Volunteerism - 2 - 1

Respect $-4-2.2$

Community $-4-2.5$

Rights $-4-2.5$

Collectivity $-4-2$

Recompense $-4-2$

Engagement - 4-2.5

Humanization - 3-2

Transparency $-3-2.7$

Action - 3- 2.7

Proactivity $-2-2$

Universality $-2-2.5$

Source: The authors.

"traditional" and "new" courses, the most prominent term is "duty", which indicates the recognition, by the students, that the doctor needs to have a degree of involvement in society.

What can be discussed on the basis of this understanding is to what extent the idea of duty transmits only the student's individual perception, rather than a collective perspective, the view of the medical school as an actor integrated in a society. Thus, there is in common to both the groups, a possibly limited understanding of social accountability. Considering that they are public university students, there is a possible notion that they must return to society the specific public investment made during their training. Even so, in studies conducted with students in the next stage of the course, the internship, it was demonstrated that only $10 \%$ of the students in the final stage of the course considered working solely in public services. And the number that want to work in small municipalities is even less: $5 \%{ }^{36}$.

The findings were similar to those from a study conducted with students of Medicine, Psychology and Dentistry, in which $80 \%$ seek to work in private consultancy, although many judged that it will be necessary to work in the public sector $^{37}$. For the authors of the study, this vision is related to the construction of an image during the training in which the liberal-private perspective is privileged and the implications of the relationships between public and private in the Single Health System (SUS - Sistema Único de Saúde) is not discussed, which ends up not contributing to the real understanding and acceptance of citizenship.

Even so, the term "citizenship" is highlighted by both the groups, principally by the group of "traditional" schools. In this group, the term is in the central nucleus, suggesting that this is more consolidated, while in "new" schools it appears in the first periphery. This perception effectively references a collective society construction and has been prominent since the preparation of the National Curricular Directives of 2001, which advocate that the course has a commitment to citizenship such that the structure includes values directed towards it ${ }^{38}$.

Thus, the term is present in the new DCN of 2014, but not with such prominence to be compared with other terms that grow substantially in the number of citations. While, according to Rocha ${ }^{15}$, there is an increase in different articles for "competences", for "citizenship" only a slight increase can be seen, being included at four points (in 2001 it was cited twice). Thus, it suggests that, even as a response to the movements for change at the start of the 2000s, the social representations of the Medical student were incorporated in the notion of "citizenship", at least for participants in this study.

Nogueira $^{39}$ argues that the arrival of the DCN in 2001 occurred in a context of questioning the technical-scientific model of medical training, with new proposals more directed to an ethical-humanist project than intended in the previous model. Thus, it is possible for the medical schools to value terms such as "citizenship" in curricular reforms that occurred at the start of the XXI century, as well as its influence on the schools created by the More Doctors Program.

Another similarity relates to the use of the term "ethics". Almeida et al. ${ }^{40}$ observed that the students had better knowledge of the Medical Code of Ethics (CEM - Código de Ética Médica) than the teachers, and both groups considered the subject of ethics extremely important, despite having little involvement in or discussion of the subject. In addition, in discussing examples given of "bad" teachers who did not observe the CEM principles, it was observed that the model of these teachers could interfere negatively in the training of the student.

Even so, it can be seen that the education on ethics in Brazil tends to be very theoretical, not very humanist and treated as a specialty, with an individualistic profile, centered on the hospital ${ }^{41}$. In this study, in comparing the curriculums of Brazilian and Cuban medical schools, the authors stated that the discussion about ethics takes place in a more continuous way in the training in Cuba. Despite this, it evaluates that there has been an increase in the quantity of subjects that address ethical issues in Brazilian curriculums ${ }^{42}$, such that the focus giv- 
en to the term in both of the groups suggests there is also an influence from the DCN of 2001, which advocates including ethical content in the structure of the Medical degree course. This proposition was maintained in full in the DCN of $2014 .^{15}$.

Having highlighted the similarities, the analysis of the differences between the groups will now be discussed. At this time, the prominence of three terms cited by the students of "new" schools can be seen: "commitment", "justice" and "SUS", principally in the first periphery and in the zone of contrasting elements. For the group from the "traditional" schools, a term highlighted in the context of this debate is "conscience".

One of the probable reasons for "commitment" being prominent in the "new" schools is the frequency with which the term appears in documents such as the Global Consensus for Social Accountability for Medical Schools ${ }^{9}$. In this document, commitment is discussed in different dimensions: the professional, serving in areas of need; the school, in working with other stakeholders in the health area; the different stakeholders regarding the principles and values of social accountability; the faculty and the students with the community. Thus, evidently, the term "commitment" refers to a more collective dimension than the terms addressed previously, and may represent an advance arising from the experiences only made possible in the courses implemented because of the More Doctors Program.

This perception of the social representations is reinforced when the term "SUS" appears cited only by the students of the "new" schools. Now, as training centered on the health system is advocated for the more recent reforms in medical education $^{6}$, the first step for the students to recognize this perspective is to understand the correlation between social accountability and the Single Health System (SUS). So much so that on analyzing the experience of an innovative school, Melo et al. ${ }^{43}$ reference the idea of longitudinal experience in the SUS, in training sensitive to the realities of the health system.

Similarly, the other consortium of schools cited in the area of social accountability, TheNET, also uses a term cited by the students of the "new schools" - "justice" - which in the case of this consortium appears when they cite their principles, including the goal of social justice. The concept of confronting injustice is directly connected to the discussion of the social determinants of health ${ }^{1}$, and in the scope of this work it is worth highlighting that the discussion of these determinants has only been incorporated in a definitive manner in the DCN since $2014^{15}$

Therefore, the appearance of terms such as "commitment", "SUS" and "justice" among the students of the "new" schools appears to signify the perspective of social accountability, even if it is a concept insufficiently implemented at national level. Adding this perception to the analysis of the profile of the students from the different schools, it can be stated that the greater incentive for the affirmative action policies and a perception more in the collective context of social accountability are possible effects of the proposals presented in the More Doctors Program.

\section{FINAL CONSIDERATIONS}

The fact that there is little national literature available on social accountability, even though Brazilian schools have developed experiences consistent with this concept, suggests that there is still not a wide understanding what this movement means to the medical schools and, consequently, still less to the students. Despite this, the appearance of the term "SUS" among the students of the "new" schools is noteworthy and, therefore, an important opportunity for these courses to value the relationship with the health system.

In addition, on analyzing the different social representations among students of "traditional" and "new" schools, important signs can be seen of how the students of "new" curriculums are forging a new path, closer to that advocated as social accountability, which is reflected in terms such as "commitment" and "justice". It can be appreciated that the modifications in the training introduced by the More Doctors Program has an important role in these changes.

It is also stressed that this analysis, as it was developed in the context of the social representations of the Medical students about social accountability, make a very specific separation between the specific context of the recently created schools and the "traditional" schools studied. It is necessary to observe how these experiences behave in a wider manner, including in the evaluation mechanisms, in the institutional or process context, including the proposals in the More Doctors Program. Therefore, other elements are required for this debate, that can be developed in new studies with different research instruments.

The changes to medical training proposed by the More Doctors Program has been a controversial subject of debates about its repercussions. Despite the disagreements, the arduous effort that many teachers are making for the country must be praised, in regions that previously did not have Medical courses, to teach the profession from the perspective of social accountability, this being a subject that needs to be pursued in the development of the teacher. These examples could be explored with the radicalism necessary to strengthen the Single Health System. 


\section{REFERENCES}

1. Buss PM, Pellegrini Filho A. A saúde e seus determinantes sociais. Physis Rev Saúde Coletiva [Internet]. 2007;17(1):7793. Available at: http://www.scielo.br/scielo. php?script=sci_arttext\&pid=S0103-73312007000100006\&ln $\mathrm{g}=\mathrm{pt \&}$ tlng=pt. Accessed on 07 sept. 2018.

2. Crisp N, Chen L. Global Supply of Health Professionals. N Engl J Med [Internet]. 2014;370(10):950-7. Available at: http:/ / www.nejm.org/doi/10.1056/NEJMra1111610. Accessed on 07 sept. 2018.

3. WHO. Increasing access to health workers in remote and rural areas through improved retention [Internet]. Vol. 23. 2010. Available at: http://www.who.int/entity/hrh/migration/hmr_expert_meeting_dolea.pdf. Accessed on 07 sept. 2018.

4. Clark TR, Freedman SB, Croft AJ, Dalton HE, Luscombe GM, Brown AM, et al. Medical graduates becoming rural doctors: Rural background versus extended rural placement. Med J Aust. 2013;199(11):779-82.

5. Ritz SA, Beatty K, Ellaway RH. Accounting for social accountability: Developing critiques of social accountability within medical education. Educ Heal Chang Learn Pract. 2014;27(2):152-7.

6. Frenk J, Chen L, Bhutta ZA, Cohen J, Crisp N, Evans T, et al. Health professionals for a new century: Transforming education to strengthen health systems in an interdependent world. Rev Peru Med Exp Salud Publica. 2011;28(2):337-41.

7. OPS. Informe Final del Grupo de Trabajo sobre Requisitos Minimos para la Creación de Escuelas de Medicina. Educ Med Salud. 1979;13(3):1-10.

8. TheNET. THEnet's Evaluation Framework for Socially Accountable Health Professional Education. Evaluation. 2011.

9. GCSA. Consenso Global de Responsabilidade Social das Escolas Médicas. 2012.

10. Menezes F, Borrell RM. La misión social de la educación médica para alcanzar la equidad en salud. 2014.

11. Woollard B, Boelen C. Seeking impact of medical schools on health: Meeting the challenges of social accountability. Med Educ. 2012;46(1):21-7.

12. Pagani R, de Andrade LOM. Preceptoria de Território, Novas Práticas e Saberes na Estratégia de Educação Permanente em Saúde da Família: O estudo do caso de Sobral, CE. Saude e Soc. 2012;21(SUPPL. 1):94-106.

13. Mahoney S, Boileau L, Floridis J, Abi-Abdallah C, Lee B. How social accountability can be incorporated into an urban community-based medical education program: An australian initiative. Educ Heal Chang Learn Pract. 2014;27(2):148-51.
14. Boelen C, Dharamsi S, Gibbs T. The social accountability of medical schools and its indicators. Educ Heal. 2012;25(3):180-94.

15. da Rocha VXM. Reformas na Educação Médica no Brasil: Estudo Comparativo entre as Diretrizes Curriculares Nacionais dos Cursos de Graduação em Medicina de 2001 e 2014. Universidade Católica de Santos; 2017.

16. Cyrino EG. Roteiro autoavaliativo de repercussões esperadas nos cursos de medicina criados a partir do MDP. Brasília - DF; 2018.

17. Dias HS, de Lima LD, Teixeira M. A trajetória da política nacional de reorientação da formação profissional em saúde no SUS. Cien Saude Colet [Internet]. 2013;18(6):1613-24. Available at: http:/ / www.scielo.br/scielo.php?script=sci arttext\&pid=S1413-81232013000600013\&lng=pt\&tlng=pt. Accessed on 07 sept. 2018

18. Cruz KT. A formação médica no discurso da cinaem. Universidade Estadual de Campinas; 2004.

19. Souza PA, Maria A, Zeferino B, Aurélio M, Ros D. Currículo Integrado: entre o Discurso e a Prática Integrated Medical Curriculum: from Discourse to Practice. Rev Bras Educ Med. 2011;35(1):20-5.

20. Oliveira FP, Pinto HA, Figueiredo AM, Cyrino EG, Oliveira Neto AV. Programa Mais Médicos: avaliando a implantação do Eixo Formação de 2013 a 2015. Interface - Comun Saúde, Educ. 2018;No prelo.

21. Brasil. Programa Mais Médicos - Dois anos: Mais Saúde para os Brasileiros. Ministério da Saúde. 2015. 128 p.

22. Abric JC. Central system, peripheral system: their functions and roles in the dynamics of social representations. Pap Soc Represent. 1993;2(1):75-8.

23. de Moura LM, Shimizu HE. Representações sociais de saúde-doença. Physis Rev Saúde Coletiva. 2017;27(1):10325.

24. Minayo MCS. O desafio do conhecimento: pesquisa qualitativa em saúde. São Paulo - SP: Hucitec; 2008. 407 p.

25. Moscovici S. Representações Sociais: investigações em psicologia social. Nova York: Polity Press; Blackwell Publishers; 2003. 404 p.

26. Franco MLPB. Representações Sociais, Ideologia e Desenvolvimento da Consciência. Cad Pesqui [Internet]. 2004;34(121):169-86. Available at: http://www.scielo.br/ pdf/cp/v34n121/a08n121. Accessed on 07 sept. 2018.

27. de Sá CP. Teoria das representações sociais: teoria e pesquisa do núcleo central. Temas em Psicol. 1996;3(1):19-33.

28. Brasil. Lei n 12.711 de 29 de agosto de 2012. Dispõe sobre o ingresso nas universidades federais e nas instituições federais de ensino técnico de nível médio e dá outras providências. Brasília - DF: Diário Oficial da União; 2012. 
29. Ristoff D. O novo perfil do campus brasileiro: uma análise do perfil socioeconômico do estudante de graduação. Avaliação Rev da Avaliação da Educ Super [Internet]. 2014;19(3):723-47. Available at: http://www.scielo.br/scielo.php?script=sci_ arttext\&pid=S1414-40772014000300010\&lng=pt\&tlng=pt. Accessed on 07 sept. 2018.

30. Haas CM, Linhares M. Políticas públicas de ações afirmativas para ingresso na educação superior se justificam no Brasil? Rev Bras Estud Pedagógicos. 2012;93(235):836-63.

31. dos Santos JT. Ações afirmativas e educação superior no Brasil : um balanço crítico. Rev Bras Estud Pedagógicos. 2012;93(234):401-22.

32. Sobrinho JD. Democratização, qualidade e crise da educação superior: faces da exclusão e limites da inclusão. Educ Soc. 2010;31(113):1223-45.

33. Costa DM, Costa AM, Barbosa FV. Financiamento Público E Expansão Da Educação Superior Federal No Brasil : O Reuni E As Perspectivas Para O Reuni 2. Rev Gestão Univ na América Lat. 2013;6(1):106-27.

34. do Nascimento GB. A política do argumento de inclusão regional no âmbito da Universidade Federal do Rio Grande do Norte. UFRN; 2015.

35. Camargo BV, Justo AM. Tutorial para uso do software de análise textual IRAMUTEQ. Universidade Federal de Santa Catarina. Florianópolis - SC; 2013.

36. de Oliveira NA, Alves LA. Ensino médico, SUS e início da profissão: como se sente quem está se formando? Rev Bras Educ Med [Internet]. 2011;35(1):26-36. Available at: http:/ / www.scielo.br/scielo.php?script=sci_arttext\&pid=S0100$-55022011000100005 \& \operatorname{lng}=$ pt\&nrm=iso\&tlng=pt. Accessed on 07 sept. 2018.

37. Ceccim RB, Armani TB, de Oliveira DLL, Bilibio LF, Moraes $M$, Santos ND. Imaginários da formação em saúde no Brasil e os horizontes da regulação em saúde suplementar. Cien Saude Colet [Internet]. 2008;13(5):1567-78. Available at: http:/ / www.scielo.br/scielo.php?script=sci_ arttext\&pid=S1413-81232008000500021\&lng=en\&nrm=iso \&tlng=pt. Accessed on 07 sept. 2018.

38. de Almeida MJ, de Campos JJB, Turini B, Nicoletto SCS, Pereira LA, Rezende LR, et al. Implantação das Diretrizes Curriculares Nacionais na graduação em Medicina no Paraná. Rev Bras Educ Med. 2007;31(2):156-65.

39. Nogueira MI. As mudanças na educação médica brasileira em perspectiva: reflexões sobre a emergência de um novo estilo de pensamento. Rev Bras Educ Med [In- ternet]. 2009;33(2):262-70. Available at: http://www. scielo.br/scielo.php?script=sci_arttext\&pid=S0100$-55022009000200014 \& \operatorname{lng}=$ pt\&tlng=pt. Accessed on 07 sept. 2018.

40. Almeida AM, Bitencourt AGV, Neves NMBC, Neves FBCS, Lordelo MR, Lemos KM, et al. Conhecimento e interesse em ética médica e bioética na graduação médica. Rev Bras Educ Med. 2008;32(4):437-44.

41. Comes Y, Díaz-Bermúdez XP, Pereira L, Oliveira FP, Caballero González JE, Shimizu H, et al. Humanismo en la práctica de médicos cooperantes cubanos en Brasil: narrativas de equipos de atención básica. Rev Panam Salud Pública [Internet]. 2017;(2):1-7. Available at: http://iris. paho.org/xmlui/handle/123456789/34585. Accessed on 07 sept. 2018.

42. das Neves Júnior WA, de Araújo LZS, Rego S. Ensino de bioética nas faculdades de medicina no Brasil. Rev Bioética [Internet]. 2016;24(1):98-107. Available at: http://dx.doi. org/10.1590/1983-80422016241111. Accessed on 07 sept. 2018.

43. Melo LP, dos Santos M, da Câmara RBG, Braga LP, e Oliveira ALO, Pinto TR, et al. A escola multicampi de ciências médicas da universidade federal do Rio Grande do norte, Brasil, no contexto do programa mais Médicos: Desafios e potencialidades. Interface Commun Heal Educ. 2017;21:1333-43.

\section{AUTHORS' CONTRIBUTIONS}

Felipe Proenço de Oliveira participated in the conception and design of the work, the writing of the manuscript and the approval of the final version of the manuscript. Leonor Maria Pacheco Santos and Helena Eri Shimizu participated in the conception and design of the work and the critical review of the results and the final version of the manuscript.

\section{CONFLICT OF INTERESTS}

The author(s) declare(s) that there is no conflict of interest regarding the publication of this article.

\section{CORRESPONDING ADDRESS}

Felipe Proenço de Oliveira, Departamento de Promoção da Saúde, Centro de Ciências Médicas, Universidade Federal da Paraíba. Campus I, Jardim Universitário, s/n, Castelo Branco. João Pessoa, PB, Brasil. CEP 58051-900.

E-mail: proenco@ccm.ufpb.br 